\title{
Notes
}

To Myres Smith McDougal, Sterling Professor of Law at the Yale Law School: By your friendship you have taught us, more deeply than scholastic inquiry or legal contest can, that the foundation of the law is the respect of one human being for another.

\section{World Hunger and International Trade: An Analysis and a Proposal for Action*}

The process by which humankind nourishes itself is unstable. That well over 400 million people are severely malnourished is stark evidence of the current imbalance in the process; under present trends, the imbalance will drastically worsen. ${ }^{1}$ Both by international prescription and by custom the United States has established a strong commitment to the right of the individual to adequate nutrition. ${ }^{2}$ This

* The research for this Note was made possible by grants from the Council on West European Studies of Yale University, the Committee on Social Responsibility in Investments of the Executive Council of the Episcopal Church, and the Presiding Bishop's Fund for World Relief of the Episcopal Church. The author expresses his gratitude for the support and encouragement represented by these grants.

1. As of mid-1974 the number of severely malnourished people was at least 460 million; at present trends it will climb to about 750 million by 1985 . STAFF of THE U.N. World Food Conference, Assessment of the World Food Situation-Present and Future 95, U.N. Doc. E/CONF. 65/3 (1974) [hereinafter cited as U.N. Food AssEssMENT]. For comparison, world population is presently about 4 billion and will be about 4.9 billion in 1985. Staff of the U.N. World Population Conference, Recent Population Trends and Future Prospects, U.N. Doc. E/CONF. 60/3, Annex II, at 3 (Table 1) (1974) [hereinafter cited as U.N. Population Assessment]. See U.N. FoOd Assessment, supra, at 102 (Table 24). The ratio of malnourished to total world population in 1975 is thus roughly 10 percent while the presently likely 1985 ratio is about 15 percent. These are conservative best estimates. The U.N. Food Assessment emphasizes this and then reiterates:

This is not just a cold statistic among statistics; it describes the daily physical privation of fellow human beings, adversely affecting health and physical growth and seriously reducing the capacity of children to learn and adults to work, as well as provoking high infant and child mortality rates. This is a conservative statistic; as such it brooks no complacency.

U.N. Foon Assessment, supra, at 5. For useful popular treatments of nutrition, food, and population matters, see G. Borgstrom, The Food and Peorle Dilemma (1974); L. Brown, BY Bread Alone (1974) [hereinafter cited as BY Bread Alone].

2. [P]rescription proceeds on three levels: (1) the designation of policy (fact contingencies, a norm and a sanction), (2) the communication of the authority of the policy and (3) the communication of control intentions of the community to sustain 
Note seeks to identify the conditions and level of new funding necessary to achieve stability and explores the corrective role international trade could play. The Note argues that the American commitment to a right to adequate nutrition, as well as personal and national security interests, warrant incorporation of nutritional stability as an objective in trade negotiations, and that the provisions of the Trade Act of $1974^{3}$ permit the easing of United States trade barriers ${ }^{4}$ in order to provide both a conduit for resources and a negotiating lever to achieve stability. The final section specifies steps that should be taken by the executive branch, agroindustry, citizens' groups, and Congress. ${ }^{5}$

it. Defined in this manner, prescription includes the outcomes both of formally authoritative prescriptive processes and of unorganized interaction.

....

In general, inherited terminology has become an obstacle to, rather than an instrumentality of, scholarship. Working within the frame of Article 38 of the Statute of the International Court ${ }^{15 i}$ and seeking to extend it to cover the myriad patterns of world constitutive prescription, scholars have been forced to invent such fabulous terms as "binding recommendations," "instantaneous custom," and "pressure-cooked custom." The emphasis on policy projection and the creation of expectations of authority and control immediately uncovers the vast and intricate web of international prescription. There is universal, general, regional, plurilateral and bilateral prescription.

Footnote 151 explains:

Article 38 , generally treated as an authoritative statement of the "formal sources" of international law, gives agreements, customs and general principles of law as the primary sources; judicial decisions and doctrinal writings as subsidiary sources.

McDougal, Lasswell \& Reisman, The World Constitutive Process of Authoritative Decision,

19 J. LEGAL ED. 403, 423-24 (1967) (footnotes omitted except footnote 151).

The most recent international affirmation of the right of the individual to adequate nutrition was adopted by the United States and 133 other nations on November 16, 1974, at the United Nations World Food Conference in Rome. This resolution affirmed that

Every man, woman and child has the inalienable right to be free from hunger and malnutrition in order to develop fully and maintain their physical and mental faculties.

REPORT OF THE WORLD FoOd Conference 1, 10, 57, U.N. Doc. E/5587, (1974) [hereinafter cited as U.N. ROME REPORT]. The United States also sponsored commitment to this right in the framing of the International Covenant on Economic, Social and Cultural Rights, as well as in the Atlantic Charter and the Constitution of the United Nations Food and Agriculture Organization. G.A. Res, 2200, annex, art. 11(2), 21 U.N. GAOR Supp. 16, at 49, U.N. Doc. A/6316 (1966); P. YATES, So Bold AN AIM 50-52 (1954) (relates the history of the first ten years of the United Nations Food and Agriculture Organization (FAO)) [hereinafter cited as So BoLD AN AIM].

In addition to explicit international declarations, however, the United States has acknowledged its commitment to the right to nutrition by habitual behavior. Actions that contribute toward embodying the right to nutrition in customary international law include the history of the United States' consistent participation in famine relief activities and the pronouncements of national leaders, for example, President Roosevelt's declaration in his "four freedoms" speech of the goal of providing adequate food for all people in all lands. Id. at 50. For a history of the evolution of this customary right of the individual to nutrition, see generally id. at 1-50; U.N. FOOD ANd AGRICULTURE ORGANIZATION, WorLd Food CoNGress (1963), REPort OF THE SECOND WorLd Food CoNGress (1970).

3. Trade Act of 1974,88 Stat. 1978, 19 U.S.C.A. $\$ \S 2101-2487$ (Supp. 1975) [hereinafter cited as Trade $\mathrm{Act}$.

4. The easing of such trade barriers as quotas and tariffs would lessen the cost or difficulty of exporting goods into the United States. See note 97 infra.

5. The diagnosis of the nutrition problem and recommendations for action have been designed to be consistent with solutions of the concurrent global problems of the war system, population pressure, exhaustion of resources, and ecological damage. For a useful 
I. The Process of World Nutrition: Assessment and Prescriptions For Stability

\section{A. Definition of the Process}

There is general recognition that nutrition actually enjoyed by the consuming population is the appropriate defining criterion for evaluating food and hunger issues. ${ }^{6}$ Five principal elements can be identified in the process by which we nourish ourselves. Recognizing these elements is essential in understanding the scope of world nutrition problems and the role of the various participants and factors that affect world nutrition. ${ }^{7}$

Demand. World nutrition demand is directly governed, although not completely determined, by population size. Currently, population growth is the cause of 83 percent of the growth of world nutrition demand, with the remaining 17 percent due to increases in consumer income that result in demand either for more food or for higher

perspective in considering these problems, prepared by a legal scholar, see R. FALK, THIS Endangered Planet 93-213 (Vintage ed. 1971) [hereinafter cited as This Endangered PLANET]. See notes 7,77 infra. This Note recommends action that relies primarily on the effective power of nation states and private industry in controlling world trade; however, this focus is in deference to the present realities of global power and is not intended to deny the desirability of reducing the concentration of power at the nation state level or in the hands of private industry. See id. at 37-45, 215-36, 353, 362-65, 382-97; M. Mesarovic \& E. Pestel, Mankind at the Turning Point 143-48 (1974) [hereinafter cited as ManKind at The TuRning Point].

6. See, e.g., A. Berg, The Nutrition Factor 1-8 (1973); By Bread Alone, supra note 1, at 20-34; So Bold AN AIM, supra note 2, at 36-37, 41, 45. See generally SENATE SELEcr Comm. on Nutrition and human Needs, 93d Cong., 2d Sess., National Nutrition Policy StUdY-Report And Recommendations I (Comm. Print 1974) (prepared by Panel on Nutrition and Food Availability), National Nutrition Policy: Nutrition and THE INTERNational Situation (Comm. Print 1974) (prepared by F. Quimby \& C. Chapman).

The focus on nutrition permits discrimination between caloric intake for energy and consumption of minerals and vitamins that provide no energy but are essential to health. The concept of nutrition thus permits diagnosis of three different aspects of undesirable nutrition:

Undernutrition: caloric, vitamin, or mineral deficiency.

Inefficient nutrition: sufficiency in calories, vitamins and minerals, but serious inefficiency in the food sources consumed for these nutrients due to the cost of the food sources consumed versus cost of alternative sources. Examples are consumption of animal protein at the expense of less costly plant protein and consuming locally grown foods that could be produced more cheaply elsewhere, or vice versa.

Overconsumption: consuming calories, vitamins, and minerals far in excess of bodily needs, often degrading the body's health. Obesity and fat deposits in arteries are typical consequences of overconsumption.

See BY BREAd Alone, supra note 1, at 32-33; U.N. Food Assessment, supra note 1, at 65-69.

7. The fundamental purpose for this analysis is to insure that any actions ultimately recommended in fact serve as solutions, and do not instead worsen or simply complicate the problem. This step is essential in the case of a problem as complex as world nutrition. The need and the method for this type of analysis of issues of law are set forth in McDougal, Lasswell \& Reisman, Theories About International Law: Prologue to a Configurative Jurisprudence, 8 VA. J. INT'L L. 188, 188-207 (1968). 
food quality per capita. ${ }^{8}$ Thus even if world population were stabilized at a constant level, nutrition demand as measured by monetary value of food would rise, as people continued to press for such improvements as more calories per meal, or more animal protein or variety in daily diet. ${ }^{9}$

Production. The production element has historically been a major focus for analysis of food and hunger issues. ${ }^{10}$ It embraces not only land-based production but fishing, ${ }^{11}$ and it spans the range from family unit farming and fishing to such institutionalized production units as large agricultural corporations and fishing fleets. Climate and local weather are significant factors in production for soil crops, ${ }^{12}$ and, for all sources of food, a vital factor in production is capital input, in the form of such implements as trucks, tractors, hand tools, animal drawn tools, water pumps and irrigation pipe, gasoline engines, harvesting machines, and silos. Another important, and sometimes neglected, aspect of production is the allocation of rights to produce comestible products. Allocation of production rights can rest largely on either private volition or central government planning, or can operate in part under central government supervision, as in the United States soil bank program, ${ }^{13}$ or under the supervision of international commodity agreement organizations, for such products as wheat or sugar. ${ }^{14}$ A principal determinant of allocation of production rights

8. In the developing market countries, population growth accounts for about 75 percent of demand growth. U.N. Foon Assessment, supra note 1, at 79 (Table 14). See J. Howe and the Staff of the Overseas Developdent Council, The U.S. ANd the DEVELOPING WORLD-AGENDA FOR ACTION 1974, at 67 (1974).

9. BY Bread Alone, supra note 1, at 25; U.N. FoOD ASSESSMENT, supra note 1, at 7, 78 .

10. Typical of the literature focusing heavily on production is G. BorGstrom, WORLD FoOd RESOURCES (1973). See generally U.N. FAO, FAO BOOKS IN PRINT 1973 (1973).

11. See U.N. FAO, FisHeries IN THE Food ECONOMY 1-6 (1968). In 1970 about 41 million tons of fish a year were consumed, compared to about 1.2 billion tons of cereals and 107 million tons of meat. It appears the oceans can presently support a total annual fish catch of about 100 million tons. U.N. Food ASSESSMENT, supra note 1, at 80, 116-17.

12. For a general introduction and detailed bibliography on this subject, see L. SMITH and the World Meteorological Organization, Weather and FoOd (1962). Some commentators argue that there is a great likelihood that some control of weather and climate will be achieved before the year 2000 -possibly long before. See, e.g., H. KaHN \& A. WIENER, The YeAr 2000, at 50, 53, 85 (1967).

13. For a description of this and other United States federal programs allocating production and distribution rights, see U.S. DEP'T OF AGRICulture, CoMpilation of Statutes (1973) (Gov't Printing Office Stock No. 0100-02789) (prepared by the Agricultural Stabilization and Conservation Service of the U.S. Dep't of Agriculture).

14. International Commodity Agreements are intergovernmental agreements regulating the production and distribution of such basic export commodities as sugar, wheat, cocoa, and coffee. Both exporting and importing countries are parties. The typical agreement creates an administrative organization and uses such regulatory devices as price floors and ceilings, export or import quotas, or buffer stocks. See U.N. FAO, AGRICULTURAL Commodity Trade and Development-Prospects, Problems and Policies 85-98, $101-17$ (1964) [hereinafter cited as FAO Commodity Tradf Document]. For recent affirmation of support for the use of commodity agreements, see Programme of Action, the Establishment of a New International Economic Order, G.A. Res. 3202, $\S I(3)(2)($ iii), 6 U.N. GAOR 
within a country is the country's economic structure. ${ }^{15}$ In market economy countries the accumulation of institutions, businesses, resources, and individuals that are associated with agriculture have been termed agroindustry. ${ }^{16}$ Agroindustry in the United States embraces firms that manufacture farm machinery and fertilizer, farmers' coop. eratives, labor unions that represent agroindustry workers, agricultural colleges, food processing firms, and financial institutions that channel funds for use by agroindustry growers, processors, and manufacturers. ${ }^{17}$

Distribution. Fundamental to distribution is the allocation of rights to obtain food, whether by means of a predominantly market-oriented economy or by means of a predominantly centrally planned economy. Distribution refers both to international and intranational allocation of food; it includes both domestic and international shipping and rail transport and such purveyors of processed food as grocers, supermarkets, village markets, government famine relief or nutritional supplement, and, in centrally planned economies, government-sponsored markets. ${ }^{18}$ Distribution also embraces the financing of food purchases through such government channels as international food aid ${ }^{19}$ or domestic food stamps. ${ }^{20}$

(Spec. Sess.) Supp. 1, at 5, U.N. Doc. A/9559 (1974). A useful analysis of a commodity agreement in practice is available in Note, Commodity Price-Fixing: The International Grains Arrangement of 1967, 23 STAN. L. REv. 306 (1971).

15. For convenience, and following the usage of the United Nations and many national governments, the world may be viewed as comprised of four categories of countries: developed market economies (such as the United States), developing market economies (such as India), developed centrally planned economies (such as the U.S.S.R.), and develop. ing centrally planned economies (such as the People's Republic of China). The boundary of the "market" and "centrally planned" dichotomy appears to be somewhat arbitrary; however, the "market" countries in general are countries that maintain a relatively higher degree of private ordering than the "centrally planned" countries, and the "market" countries generate nearly 90 percent of all international trade. U.N. FooD AssEsSMENT, supra note 1, at 125; FAO CoMmodity TRADE Document, supra note 14, at 107, 109; U.N. Dep't of Economic and Social AfFairs, Yearbook of International Trade Statistics 1972-1973, at 22 (Table B) (1974) [hercinafter cited as UN 1972-1973 Trade Statistics].

16. See, e.g., Staff of THE U.N. World Food Conference, Report of the Consultation with Agroindustrial Leaders i-ix, U.N. Doc. DDI:G/74/89 (1974) [hereinafter cited as U.N. AGROINDUSTRY REPORT].

17. Representative firms and institutions include American Can Co., Cargill Inc., International Harvester Corp., Deere \& Co., Dow Chemical Co., Nabisco Inc., Connecticut General Insurance Corp., and the Inter-American Development Bank. Id. at i-ix.

18. See A. Galston \& J. Savage, Daily Life in People's China 160 (1973).

19. Summation of data from United Nations statistics indicates that total world food assistance in 1973, including all private and public loans and grants and direct food shipments, was on the order of $\$ 3$ billion, of which about half was in the form of food for immediate use and half in the form of investment funds for increasing food production. See U.N. Food Assessment, supra note 1, at 45; STAFF of THE U.N. WorLd Food Conference, The World Food Problem-Proposals for National and International. ACTION 131, 187, U.N. Doc. E/CONF. 65/4 (1974) [hereinafter cited as U.N. Food Proposals].

20. Food Stamp Program, 7 U.S.C.A. $\$ \$ 2011-26$ (1973). 
Storage. Storage functions principally to preserve food in order to provide reservoirs for use in modulating the effects of fluctuations in the underlying demand, production, and distribution trends. ${ }^{21}$ Storage is needed for the intermittent shortages caused by such changes as floods, droughts, earthquakes, war, and economic or political collapse. Presently, nations and public and private international organizations work together ad hoc to supply the nutrition needs posed by these events. ${ }^{22}$ Usually, the organizations and national governments providing the relief purchase the necessary food stocks from their own domestic or foreign markets. ${ }^{3}$

Information. The elements of the world nutrition process are interdependent parts of an integrated system and the participants in each element rely on information concerning the other parts. For example, regional preparations for storage expansion depend on information about production and regional population growth; agricultural machinery production turns on plans for crop production and harvesting; and food shipment arrangements turn on crop size, need to tap or replenish storage, and the size and location of regions with an undesirable nutrition condition, as indicated by undernutrition, inefficient nutrition, or overconsumption. ${ }^{2+}$ In market economies, a great deal of supply and demand information is conveyed by price. Governments in both centrally planned and market economies also collect information directly, as do such international organizations as the Food and Agriculture Organization of the United Nations, the Wheat Council, and the international development banks. ${ }^{25}$

\section{B. Assessment of the Process}

In 1974 the United Nations convened the World Food Conference in Rome $^{20}$ and the World Population Conference in Bucharest. ${ }^{27}$ The conferences served two major purposes. One was political: as as-

21. U.N. Food and Agriculture Organization, Functions of a World Food ReserveScOPE AND Limitations 3-10, 18 (1956) [hereinafter cited as FAO RESERVE ANALYSIS]; U.N. Food Prorosals, supra note 19, at 12, 171-75.

22. Interview with R. Neil Macdonell, External Relations Officer, World Food Program, in Rome, Italy, Oct. 3, 1974 (notes on file with the Yale Law Journal).

23. Id.

24. For a definition of these conditions, see note 6 supra.

25. U.N. Food Assessment, supra note 1, at 44; U.N. Food Proposals, supra note 19, at 167.

26. The conference was held November 5-16, 1974. Robbins, Food Conference, in Last Day, Forms New U.N. Agency, N.Y. Times, Nov. 17, 1974, at 1, col. 8.

27. The conference was held August 19-30, 1974. REPort of the Wordd Population Conference, 1 U.N. Doc. E/5585 (1974) [hereinafter cited as U.N. Bucharest REPORT]. 
semblies of official diplomatic representatives, ${ }^{28}$ they supplied a political platform for thrusting hunger and population issues into the world consciousness. Action on these issues depends on political will, and political will depends on the mobilization of concern. ${ }^{23}$ However, the Bucharest and Rome conferences served a less publicized or scrutinized second purpose: establishing and presenting the spectrum of data bearing upon food and population. The data prepared for use at the conferences was accumulated by the United Nations and participating countries with the help of a wide range of organizations and individuals, including the World Bank, the Food and Agriculture Organization, and the Ford Foundation. ${ }^{30}$ That material makes it possible to assess the condition of the process of world nutrition. Demand, Production, and Distribution. On the basis of the Bucharest and Rome data, there is likely to be no shortage in food produc-

28. Id.; Robbins, Delegates Gather in Rome for World Talks on Food, N.Y. Times, Nov. 5, 1974, at 14, col. 7 . The fact that the delegates spoke for their governments enhanced the impact of the Rome deliberations; at the two World Food Congresses in 1963 and 1970, for example, delegates came and spoke solely in their personal capacities. U.N. FAO, WORLd FoOd CoNGress 8 (1963), Report of THE SECOND WORLD Food Congress 6 (1970).

29. Environment issues enjoyed this political elevation in Stockholm in 1970 , the use of the sea's resources in Caracas in 1974, and world trade in Geneva as evidenced by the Kennedy Round of trade negotiations begun in 1964. See generally Stevenson \& Oxman, Preparations for the Law of the Sea Conference, 68 AM. J. INT'L L. 1 (1974); Note, New Perspectives on International Environmental Law, 82 YALE L.J. 1659 (1973); STAFF of the Senate Comm. on Finance, 93d Cong., 2d Sess., Summary and Analysis of H.R. 10710The Trade Reform Act of 1973, at 1, 67 (Comm. Print 1974) [hereinafter cited as Senate Trade ANalysis] [The proposed Trade Reform Act of 1973 was eventually enacted as the Trade Act of 1974, supra note 3]; U.S. DEP'T OF AGriculture, REPORT oN the Agricultural Trade Negotiations of the Kennedy Round iii, 1 (1967).

30. Interview with Dale Hathaway, Program Advisor, The Ford Foundation, in Rome, Italy, Sept. 23, 1974. The conference material includes the U.N. Foon AssessmeNr, supra note I, and U.N. Foon Proposals, supra note 19. Analyzing the worldwide evidence and writing on food and population issues and consolidating it into manageable form were themselves functions of the information element of world nutrition. They were also a major achievement, creating a valuable departure for analysis of nutrition throughout the world, although to date the value of the material has not enjoyed wide recognition, probably due to the overshadowing effect of the political aspects of the conferences. The accuracy and completeness of the food conference material was affirmed by the agricultural, monetary, and diplomatic representatives of many delegations, and is probably due largely to the series of three preparatory committee meetings held in the year preceding the conference and attended by most of the delegations of the conference. Minutes of the Third Session of the Preparatory Comm. for the World Food Conf., Rome, Sept. 23Oct. 4, 1974 (prepared by the author at the Session and on file with the Yale Law Journal), Declarations in Plenary Session of the Delegates of the Philippines, Yugoslavia, Colombia, Indonesia, and Venezuela (Sept. 25 session) and the United States and Denmark (Sept. 26 session). Some criticisms of the material were that it gave insufficient attention to land reform (Sudan, Sept. 25), broad economic and social reform (U.S.S.R., Sept. 25), the need to balance population and food supplies (Nigeria, Sept. 23; United States, Sept. 26; Cuba and Philippines, Sept. 27), and overconsumption (see note 6 supra) in developed countries (Norway, Sept. 25). A survey of the material prepared for the World Population Conference indicates similar completeness and accuracy. See, e.g., STAFF OF THE WorLD Population Conference, Summaries of Background Papers Commissioned for the World Population Conference, U.N. Doc. E/CONF. 60/CBP/35 (1974). 
tion capacity at the world level through $1985 .{ }^{31}$ The world nutrition problem through 1985 arises instead from the distribution element: at present trends, hungry countries will not have sufficient foreign exchange to buy food from the countries that can produce food. ${ }^{32}$ In 1985 this gap will be at least $\$ 17$ billion per year, in 1973 dollars. $^{33}$ The gap will lie entirely in about 30 developing market economy countries. ${ }^{34}$ No developed market economy countries will have shortages, and no developed or developing countries with centrally planned economies will have significant shortages. ${ }^{35} \mathrm{But}$ it is also evident that the centrally planned economies will probably be able to feed only themselves, with little surplus. ${ }^{36}$ Thus, those developing countries that can be broadly characterized as committed to relatively high degrees of private volition and private ordering, the market economies, are

31. U.N. Food Assessment, supra note 1, at 99 (emphasis added):

From the foregoing analysis of the food problem of the future a great many conclusions could be drawn leading to policy suggestions in various fields, and different individuals would probably single out different items. Thus, some might focus attention on that aspect of the arithmetic which shows no 1985 imbalance in food supplies at world level and might be content to express satisfaction that world production appears capable of satisfying effective commercial demand.

32. Id. at 7 (emphasis added):

The expected divergence between the growth of demand and the growth of production in the developing countries would mean a trend toward greater and greater dependence on food imports. In cereals the deficit of the developing market economy countries would, according to these trends, rise by 1985 to around 85 million tons per year, compared with 16 million tons of net imports in $1969 / 72$. The payments aspect of this vast import can be visualized when it is reckoned that at the 1973/74 average price of cereals of US\$200 per ton, an expenditure of $\$ 17$ billion per annum would be involved; and these countries would also be needing imports of other foods besides cereals. It is clear that under the existing trade arrangements, the majority of cereals importing developing countries would not be able to finance such heavy imports.

33. Id. This gap assumes the per capita rate of consumption in the developed countries will continue. However, the size of the gap could be diminished somewhat if presently well- and over-fed peoples modified their eating habits, so that instances of overconsumption and inefficient nutrition (see note 6 supra) were eliminated. This would lower the demand for food in the developed countries, thereby lowering the price, so that poorer purchasers could acquire more grain for a given amount of payment. The Food Conference staff noted:

In industrialized countries and in the economically privileged minorities of the less developed nations, the problem of overconsumption should be considered, because it leads to physical deterioration and certain degenerative diseases, and is also generally coexistent with large food wastage.

Id, at 139 .

34. Id. at 88-89, 91 (Table 21), 93 (Table 22). The report does not list them, but they include Bangladesh, Central African Republic, Chad, Dahomey, El Salvador, Ethiopia, Ghana, Guinea, Guyana, Haiti, Honduras, India, Ivory Coast, Cambodia, Laos, Lesotho, Madagascar, Mali, Mauritania, Niger, Pakistan, Senegal, Sierra Leone, Somalia, Sri Lanka, United Republic of Cameroon, United Republic of Tanzania, Upper Volta, Yemen (A.R.), Yemen (D.R.). Rensberger, 32 Nations Close to Starvation, N.Y. Times, Oct. 20, 1974, § 4 , at 4, col. 1 (citing FAO and U.N. Statistics); Letter from Norman R. Michie, Information Liaison Officer, FAO, to John P. Wheeler III, Jan. 10, 1975 (on file with the Yale Law Journal). The letter is based on cereal data alone, so that it lists only 17 Group I countries; the list expands to over 30 when all foods are considered.

35. U.N. Food AsSEssmeNT, supra note 1, at 91 (Table 21), 93 (Table 22).

36. Id. 
the very countries for whom major nutritional gaps are most likely.

The staff of the World Food Conference divided the developing market countries into three groups: the developing market countries with a permanent nutrition gap were designated as Group I countries, those that are self-sufficient or dependent on foreign exchange earnings for their sufficiency as Group II, and the food exporters as Group III. ${ }^{37}$ India, Honduras, and Sri Lanka are representative of Group I, Egypt and Peru of Group II, and Argentina and Thailand of Group III.38 Because of their likely crop gaps in 1985 and their limited export markets, the Group I countries will not be able to feed themselves, even allowing for the highest politically feasible amounts of direct financial aid for buying food. ${ }^{38}$

The Group II economies are also in fragile balance. Many of the Group II countries could be self-sufficient in food production, or nearly so. ${ }^{40}$ However, in order to maximize their foreign exchange earnings they instead produce cash crops for export, relying on the earnings to import food. ${ }^{41}$ In many of these countries both nutrition and political stability depend on stability of access and sales to foreign markets. ${ }^{42}$ Their markets lie overwhelmingly in the developed market countries (about 20 percent in the United States and 50 percent in other developed market countries) and other developing market countries (about another 20 percent, with the remainder in centrally planned countries). ${ }^{43}$ In times of poor crops in their own country or

37. U.N. Food Proposals, supra note 19, at 211-17.

38. Group I countries are listed in note 34 supra. There are few, but at least eight, Group III countries: Argentina, Brazil, Burma, Mexico, Morocco, Thailand, Turkey, and Uruguay. The Group II countries are the remaining developing market economies. Letter from Norman R. Michie, supra note 34 .

39. U.N. FOOD Proposals, supra note 19, at 9, 211-14.

40. Id. at 214

41. Id.

42. Hearings on the Trade Reform Act of 1973 Before the Senate Comm. on Finance, 93d Cong., 2d Sess. 453, 487 (1974) (testimony of Secretary of State Kissinger) [hereinafter cited as Trade Hearings].

43. U.N. 1972-73 TRAde Statistics, supra note 15, at 22 (Table B); J. Howe ANd THE Staff of the Overseas Development Council, The U.S. ANd the Developinc WorldAGENDA FOR ACTION 1974, at 156.57, 165 (Tables B-1, B-8) (1974) [hereinafter cited as odC Agenda]; Staff of the Senate Comm. on Finance, 93d Cong., 2d Sess., Staff Data on U.S. Trade and Balance of Payments 41 (Fig. 7), 42 (Fig. 8) (Comm. Print 1974) [hereinafter cited as SENATE TRADE DATA]. As measured by the total value of exports, world trade in 1973 stood at $\$ 575$ billion. SENATE CoMM. ON FinaNCE, 93D Cong., 2D Sess., Report on the TRADE Reform ACt of 1974, at 6 (1974) [hereinafter cited as SEnate Trade Act ReporT] (the Trade Reform Act of 1974 was enacted as the Trade Act of 1974, supra note 3). Worldwide, United States exports in 1973 were about $\$ 70$ billion. Total developing market country exports were about \$107 billion, of which about $\$ 46$ billion was petroleum exports, leaving a total of about \$61 billion of nonpetroleum related exports. Id.; SEnATE TRADE DATA, supra, at 1, 31 (Tables 1, 31). In the developing market countries, the ratio of exports to GNP was therefore about 20 percent; for the United States, the figure was about 5 percent. Id. at 38 (Fig. 1). Total United 
in the grain exporting countries they may not have the food or the foreign exchange necessary to fill their nutrition gap, especially as their populations rise. ${ }^{44}$ Only the Group III countries are likely to be insulated from shortfalls. ${ }^{45}$

After 1985, at present trends, increases in demand due principally to population growth will put increasing pressure on world food production capacity. At present growth rates, and with allowance for those population control programs now in effect or planned, world population will increase about 50 percent by the year 2000, reaching about 6.4 billion from the present level of about 4 billion. ${ }^{46}$ At least one-half billion of this increase will occur in the 30 Group I countries, the countries which will certainly be unable to feed themselves by 1985 and therefore hopelessly so by $2000 . .^{47}$ About another 1 billion of the increase will occur in the Group II and III developing countries; roughly one-fourth billion of the increase will occur in the developed market and centrally planned countries; and three-fourths billion will occur in the developing centrally planned economies. ${ }^{48}$ The same trend will push total world population to about 11 billion by $2050,{ }^{49}$ a trend which under presently forecasted technology the world cannot support, and which, if not altered by deliberate planning, will likely be altered catastrophically, through some combination of war, famine, and disease. ${ }^{50}$

States imports from developing market countries were about $\$ 20$ billion, including about $\$ 9$ billion of petroleum imports; United States exports to developing market countries were about \$21 billion. Id. at 42 (Fig. 8), 31 (Table 31).

44. U.N. Food Proposals, supra note 19 , at $28,214$.

45. Id. at 214-15.

46. Staff of the U.N. World Population Conference, Recent Population Trends and Future Prospects, U.N. Doc. E/CONF. 60/3, Annex II, at 3 (Table 1) (1974) [hereinafter cited as U.N. Population Assessment].

47. Id. at 4 (Table 2).

48. Id.

49. U.N. Secretariat, World and Regional Population Prospects, U.N. Doc. E/ CONF. 60/CBP/15, at 31 (Table 9) (1974) [hereinafter cited as U.N. Regional Prospects].

50. L. BRown, IN THE HUMAN INTEREST $171-86$ (1974) [hereinafter cited as IN THE Human INTEREST]. The author cites, inter alia, the President of the World Bank: "Robert IcNamara has articulated it well: "The population problem will be solved one way or another. Our only option is whether it is to be solved rationally and humanely or irrationally and inhumanely." Id. at 171. See D.H. MEADows, D.L. MEadows, J. Randers \& W. Behrens, The Limits to Growth 142 (1972) (emphasis in original):

Although we have many reservations about the approximations and simplifications in the present world model, it has led us to one conclusion that appears to be justified under all the assumptions we have tested so far. The basic behavior mode of the world system is exponential growth of population and capital, followed by collapse. As we have shown in the model runs presented here, this behavior mode occurs if we assume no change in the present system or if we assume any number of technological changes in the system.

Modes of collapse are discussed at $188-89$ (emphasis added):

It is true that in practice events take place in the world sporadically at points of stress-not generally or simultaneously throughout the planet. So, even if the consequences anticipated by the model were, through human inertia and political 
Storage and Information. The present pattern of relying on market purchases for famine relief and for covering harvest shortfalls has proved inadequate in the past, and will be increasingly unsatisfactory in the future, principally because of delays in acquiring food for famine relief by purchase ${ }^{51}$ and because of the limits on the size of unplanned purchases that the world food markets can bear in any given year. ${ }^{52}$ There is a need for a system of food reserves to buttress the system of market purchases in times of shortfall. ${ }^{53}$ Presently, about 100 million tons of cereals are maintained in reserve worldwide; to achieve a minimum safe food reserve for the 1975 level of world population, about 50 million additional tons of cereals, or the equivalent in other forms of food, would have to be accumulated and stored worldwide. ${ }^{54}$ These storage needs extend not only to harvested food but to seed stocks, ${ }^{5 \bar{v}}$ and, since stocks do not last indefinitely, reserved food and seed regularly would have to be distributed and replaced by freshly harvested substitutes. ${ }^{56}$ Moreover, there is a need for more prompt and comprehensive information collection on the probable size of each season's harvests throughout the world, in order to anticipate shortages and consequent demands on food storage. ${ }^{57}$ Such information becomes increasingly important as 1985 approaches, as the balance between population and food supplies becomes more delicate: the more taut the world system of demand, production, and distribution, the harder it will be to supply periodic shortfalls in production. A major information gap arises from the actions of the centrally planned economies, most notably the Soviet Union and the People's Republic of China: these countries do not generally share

difficulties, allowed to occur, they would no doubt appear first in a series of local crises and disasters.

But it is probably no less true that these crises would have repercussions worldwide and that many nations and people, by taking hasty remedial action or retreating into isolationism and attempting self-sufficiency, would but aggravate the conditions operating in the system as a whole. The interdependence of the various components of the world system would make such measures futile in the end. IVar, pestilence, $a$ raw materials starvation of industrial economies, or a generalized economic decay would lead to contagious social disintegration.

Some analysts have questioned the inevitability of this outcome under current trends and have criticized the techniques used in projecting the outcome, although they concur in the urgency of the problems and the possibility of catastrophic results. See, e.g., Humanist Interview with Herman Kahn, THE HuMANIST, Nov.-Dec. 1973, at 42.

51. Interview with R. Neil Macdonell, supra note 22.

52. Id.

53. U.N. Food Proposats, supra note 19, at 165. Proposals for international coordination of staple resources, including grain, are not new. See, e.g., Keynes, The International Control of Raw Materials, 4 J. INT'L ECoN. 299 (1974) (a 1942 memorandum by John Maynard Keynes).

54. Id. at 173 .

55. Interview with R. Neil Macdonell, supra note 22.

56. Id.

57. U.N. Food Proposals, supra note 19, at 167-69. 
their crop forecasts, so that it is difficult to predict the size and timing of any interventions they may make on world markets..$^{58}$

\section{Prescriptions for Stability}

Production and Distribution. The potential annual food import gap by 1985 in the Group I countries, well over $\$ 17$ billion in 1973 dollars, ${ }^{50}$ exceeds the annual sum of any likely foreign aid and export earnings that the Group I countries can be expected to acquire. ${ }^{60}$ Therefore, the gap must be filled slowly, starting now, by enabling the Group I countries to produce enough food by 1985 that any remaining need for food imports each year will be manageable, either through direct aid or through purchase with their foreign exchange. ${ }^{61}$ Similarly, those Group II countries that are vulnerable to food shortages due to fluctuations in their foreign exchange earnings should be encouraged and enabled to enlarge their domestic food production. ${ }^{62}$ In addition, food production in the Group III countries, as well as in the nutritionally self-sufficient Group II countries, should be expanded in order to increase the supply of food available to Group I and Group II countries that have food shortfalls. ${ }^{63}$ The total additional foreign exchange which the Group I, II, and III countries must invest in food production in order to achieve these goals is $\$ 2$ to $\$ 2.5$ billion per year through 1985, expressed in 1973 United States dollars. ${ }^{04}$ This is the total foreign exchange gap: it is over and above presently projected levels of foreign exchange earnings, loan funds, and direct aid. ${ }^{\circ 5}$

58. By BrEAd Alone, supra note 1, at 230.

59. See note 32 supra.

60. U.N. Food Assessment, supra note 1, at 99; U.N. Food Proposals, supra note 19, at 23. Total food-related aid in 1973 was on the order of $\$ 3$ billion. See notes 19, 39 supra.

61. This was the conclusion of the food conference analysts. U.N. Food Proposals, supra note 19 , at 212-14.

62. Id. at 214. See note 38 supra (countries comprising Groups I, II, and III).

63. U.N. Food Proposals, supra note 19, at 214-15.

64. Id. at 134:

Without great new initiatives to increase external funding, the amounts of [food production] funds will fall far short of requirements. Despite significant shifts in priorities to agriculture and to small farmers, the World Bank resources foreseen for allocation to agriculture, while they are expected to double in real terms in the next five years, are not likely to exceed US\$2 billion annually. Other multilateral agencies and bilateral donors, given present indications, may increase their financing of agricultural programmes to about US\$700 to US\$750 million. There is thus need to mobilize an additional amount of US\$2 to US\$2.5 billion annually for achieving the suggested targets of food production in developing countries.

This need could be reduced somewhat if overconsumption and inefficient nutrition, especially in developed countries, were greatly reduced. See note 33 supra.

65. Id. This investment total assumes the operation of the multiplier effect of the funds on the GNP of the recipient countries, that is, the $\$ 2$ to $\$ 2.5$ billion total represents 
Demand. Nutrition balance in the post-1985 period requires correction of the demand element; the component of food demand caused by population size must be stabilized. ${ }^{60}$ There is inertia in population growth, so that world population would grow for several decades even if birth rates were sharply reduced. ${ }^{67}$ The reasons for this include lengthening life expectancy and a greater number of people at marrying age, due to increased births in the past. ${ }^{68}$ Thus, steps taken in 1975 to reduce world population growth would not reflect significant results in total world population until at least 1985 and perhaps even later, ${ }^{69}$ although steps to increase food production in developing market countries can strike a balance between growing food supply and increasing demand through about the same year. ${ }^{70}$

Although allowance must be made for the characteristics of individual countries, including such countries as Argentina and Canada

the initial input needed as an external injection into the recipient countries. U.N. Foon Proposals, supra note 19, at 134 . For a discussion of the operation of the multiplier effect on funds that enter a country, see J. Young, The INTERnational Economy 130-41 (1963).

Given the investment funds, the principal determinant of the success of a program of increased food production is the political will of the recipient countries: they must fashion and enforce the specific fiscal policies necessary to expand agricultural production. U.N. Foon Proposals, supra note 19, at 23, 27-30, 131. These same policies must also ensure that the food increases are in fact available to the hungry within the country. Id. Essential to the delivery of food is the provision of employment:

The key element is the involvement of the people, particularly the underprivileged and the poorest among them, in the processes of economic and social development. Unless and until that is achieved, the technology, fertilizer or available water and other resources will not be utilized adequately or efficiently; the food that is produced will not be distributed equitably and the entire structure of the rural society will remain under the stresses emanating from growing unemployment and undiminished hunger.

$I d$. at 105 . In calculating the net annual gap of $\$ 2$ to $\$ 2.5$ billion for investment in food production, the Food Conference staff assumed that the labor for the projected agricultural expansion would come from the presently un- or under-employed, who would thereby be enabled to acquire finished food. Id. at 105-34. Lester Brown treats the employment and poverty problem in the same manner. IN THE HuMAN INTEREST, supra note 50 , at $120-27$. One necessary policy in this regard appears to be to emphasize labor intensive agricultural expansion, in order to broaden the employment base. Id. at 121-22. There is a sizable literature that sets forth and analyzes the alternative policies that can be taken within a country to convert available investment funds into specific results in production and delivery of food, employment of labor, and control of population growth. See U.N. FAO, Marketing Problems and Improvement Programs (1958); U.N. FaO, New ApProach to Agricultural Credit (1964); U.N. FAO, Agricultural Credit through Co-operatives AND OTHER INSTITUTIONS (1965); U.N. FAO, AGRICULtURE AND INdUSTRIALizATION (1967); U.N. FAO, PRINCIPLes of LAND Consolidation Legislation (1962); U.N. FAO, Land Reform-Land Setrlement and Cooperatives (1973); U.N. FÁO, The United Nations, Human Fertility and National Development, U.N. Doc. ST/ECH 138 (1971); Kuznets, Population and Development in Perspective, U.N. Doc. E/CONF. 60/CBP/7 (background paper dated March 18, 1974, prepared for the U.N. for the World Population Conference in Bucharest).

66. See note 8 supra.

67. U.N. POPULATION Assessment, supra note 46, at 20-21.

68. Id.

69. IN THE HuMAN INTEREST, supra note 50, at 148-58.

70. See note 31 supra. 
where larger populations may be desirable goals, ${ }^{71}$ specification of some general averages can serve to depict the magnitude of change that is necessary. World population can be stabilized at about six billion by roughly the year 2000 if the average birth rate and death rate per thousand ${ }^{72}$ for the developed market and developed centrally planned countries are brought into offsetting balance by 1985 and the average birth rate per 1000 for all the developing countries is reduced to 25 by $1985^{73}$ and to offsetting balance with their death rate by about the year 2000.74 The centrally planned countries and the developed market countries already appear to be headed toward these rates or to be able to achieve them..$^{\tau 5}$ The developing market countries, however, currently plan to fall to a level of roughly 29 births per 1000 by 1985 , from a 1975 average of $35 .^{76}$ Thus, if the developing market countries could adjust to and realize a goal of an additional planned decline of about 4 births per 1000 by 1985 , they would have

71. These and a number of other countries have geographical areas in which increased population is probably a desirable goal, and one which probably cannot be achieved by migration alone. See, e.g., Staff of the U.N. World Population Conference, Summary Country Statements Concerning Population Change and Develorment 5-6, 11 , U.N. Doc. E/CONF. 60/CBP/33 (1974) [hereinafter cited as Population and Development STATEMENTS].

72. The birth rate is the annual number of live births per 1000 persons of the total population. Since this can be affected by variations in the population age structure, it is also often referred to as the "crude" birth rate. The death rate is the average annual deaths per 1000, also called the "crude" death rate. U.N. Population Assessment, supra note 46, Annex I, at 1 .

73. IN THE HUMAN INTEREST, supra note 50, at 149-53, 157.

74. Id. at 153 (citing 2015 as the year when death rates and birth rates could settle in offsetting balance).

75. Id. at 158. In explaining its population policy, the government of the People's Republic of China states:

China pursues a policy of developing its national economy in a planned way, including the policy of planned population growth. We do not approve of anarchy either in material production or in human reproduction.

Man should control himself as well as nature. In order to realize planned popula. tion growth, what we are doing is, on the basis of energetically developing production and improving the people's living standards, to develop medical and health services throughout the rural and urban areas and strengthen our work in maternity and child-care, so as to reduce the mortality rate on the one hand and regulate the birth rate by birth planning on the other.

Porulation and Development STATEMENTs, supra note 71, at 13.

The United States Government reports:

The United States Commission on Population Growth and the American Futureestablished at the President's request by the United States Congress in 1970-concluded that it could find no substantial economic or social benefit to be derived from continued United States population growth beyond that made unavoidable by past demographic trends. In the Commission's judgment, the time has come for the United States to welcome and plan a deliberate policy to stabilize population growth in the interest of socially desirable ends.

Id. at 66 (emphasis added).

76. Their goal is an annual growth rate of 2 percent by 1985. U.N. BUCHAREST REPORT, supra note 27, at 10-11. This corresponds to an average birth rate in the developing market countries of 29. U.N. Regional Prospects, supra note 49, at 8 (Table 1), 11 (Table 2). 
embarked on a program that could stabilize world population at about six billion by the turn of the century. World food production and distribution can probably permanently sustain a population of that size by the year 2000, assuming that in the years from 1975 to 1985 the level of food production in developing market countries is increased to a level sufficient to deliver adequate food to their 1985 population. ${ }^{77}$

The population planning experiences of the People's Republic of China, Taiwan, India, South Korea, Cuba, Argentina, Chile, and Uruguay indicate that this total average reduction from the present level of 35 to a level of 25 births per 1000 is feasible. ${ }^{78}$ In the experience of these countries, the most effective control of population size appears to be economic and social development, which works over time to create conditions that lead families to want fewer children. ${ }^{79}$ The reasons for this are complex and not well understood, so that the relationship of lower birth rates, and economic development may be one of correlation, rather than direct cause and effect. The principal contributions of economic and social development to lower birth rates apparently include a rising level of popular education and literacy, the diminished importance of large families as production units, and achieving, and becoming accustomed to, reduced child mortality. ${ }^{80}$ Also at least modestly important are such direct government programs as public indoctrination in family planning and provision of contraceptives. ${ }^{81}$ Legislated increases in the legal age for marriage also appear to be of some possible importance. ${ }^{82}$ On the other hand, the slow pace of the general economic and social development in the developing market countries and the competition within those coun-

77. Projected world population in 1985 is about 4.9 billion. See note 1 supra. Assuming humankind were being fed adequately in 1985 at a total population of 4.9 billion, food production would have to increase about 21 percent by the year 2000 in order to match the 21 percent increase of population from 4.9 billion in 1985 to 6 billion in 2000. This would require food production increases of about 1.1 percent per year between 1985 and 2000 , a goal which appears reasonable, in light of the currently projected 1975 to 1985 increase of food production in excess of 2.7 percent per year. However, it must be stressed that these figures are based largely on projections of past trends and do not reflect the effects of war. U.N. Food AssessMeNT, supra note 1, at 87. There is an issue as to whether the earth's ecological balance and resource stocks, particularly chemicals needed for fertilizer, can permanently sustain food production sufficient for six billion human beings. Research on this question is not extensive, but the available evidence is that under a scheme of stabilized population size and increased food production in developing countries, as proposed in this Note, the earth can support a population of six billion. MANkind AT THE TURning PoINT, supra note 5, at 115-29; THIS ENDANGERED PlaneT, supra note 5, at 353-413, 431-37.

78. IN THE HUMAN INTEREST, supra note 50, at 153-58.

79. U.N. Population Assessment, supra note 46, at 31-35.

80. Id.; IN THE HUMAN INTEREST, supra note 50, at 162-66.

81. Id. at $36-38$.

82. Id. at 38-39. 
tries for the funds and resources needed to expand such governmentrun direct population control programs as family planning clinics constitute the principal obstacles to reaching the stabilization goal. ${ }^{83}$ Stabilization of world nutrition demand plainly requires acceleration of general economic development in the developing market countries and augmentation of funds used in those countries for direct population control programs.

The economic cost of achieving this population stabilization goal can be estimated by summing the cost of those social improvements made possible by general economic development that appear to be most significant in inducing reduced birth rates. The most significant improvements appear to be adequate food supply, literacy, adequate family planning services, adequate prenatal and postnatal health care for children and mothers, and opportunity for productive employment. ${ }^{84}$ The incremental cost for adequate food production in the developing market countries has been estimated at $\$ 2$ to $\$ 2.5$ billion in 1973 United States dollars per year through 1985.85 Achieving substantially universal literacy in the developing market countries would cost about another $\$ 1$ billion per year through $1985 .{ }^{80}$ Adequate maternal and infant health care and family planning services would cost about another $\$ 2$ billion per year. ${ }^{87}$ It appears that the requisite employment opportunities can be provided by the job increases in the expanded agricultural sector and the industries that support the sector, so that employment expansion is encompassed by the $\$ 2$ to $\$ 2.5$ billion for food production. ${ }^{\mathrm{s}}$ Thus, population stabilization by about the year 2000 in the developing market countries requires additional funds of about $\$ 3$ billion per year through 1985 , in addition to $\$ 2$ to $\$ 2.5$ billion for food production.

Storage and Information. "Storage" may conjure the image of a few central superwarehouses but the most workable concept appears to be a large system of small collection points throughout the world, with some allocation and collection power under national control and some under regional or global international control. ${ }^{89}$ In order to give the

83. IN THE HUMAN INTEREST, supra note 50, at 159-66.

84. U.N. Population Assessment, supra note 46, at 31-35; IN THE HuMan INTEREst, supra note 50 , at $162-66$.

85. See p. 1057 supra.

86. IN THE HUMAN INTEREST, supra note 50, at 163 .

87. Id. at 165 .

88. See note 65 supra. As in the case of increased food production, the principal determinant of the success of such a birth rate reduction program is the political will of the countries involved and the success of the fiscal policies they use to achieve the birth rate goals.

89. U.N. Food Proposals, supra note 19, at 174-75; BY Bread Alone, supra note 1, at 226-30. 
storage system sufficient leadtime in arranging for drawdowns, harvest forecast information must be assembled more quickly than is the current practice,,$^{90}$ and attempts should be continued to obtain forecasts from those centrally planned countries that are likely to make demands on the world markets from time to time. Currently, it appears possible that crop monitoring by earth satellites will be capable of providing continuous global crop information, at low $\operatorname{cost}^{, 11}$ although there may remain the need for assent, or lack or formal objection, to such monitoring from the Soviet Union and the People's Republic of China. ${ }^{92}$ Achieving minimum safe storage levels and adequate early warning information in the market economies would cost approximately $\$ 1.5$ billion per year, in 1973 United States dollars, through 1985.93

\section{The Role of International Trade in Stabilizing World Nutrition}

\section{A. Effectiveness in Transferring Wealth and Resources}

Inducing lower birth rates by promoting general economic development, increasing domestic food production, and providing adequate food storage and information in the developing market countries would require additional annual investment in those countries, over and above presently projected increases, of about $\$ 6.5$ to $\$ 7$ billion per year through 1985 , for a ten-year flow of about $\$ 65$ to $\$ 70$ billion. ${ }^{94}$

90. U.N. Food Proposals, supra note 19, at 167-69.

91. Id.; U.N. FAO, USE OF ERTS-13 IMAGERY FoR FAO INTEGRATEd RESOURCE SURveYS, U.N. Doc. AGS:MISC/73/20, at ii, 8 (1973).

92. For an analysis of the legal issues involved in reconnaissance from space, see $M$. McDougal, H. Lasswell \& I. Vlasic, Law and Public Order in Space 69, 224, 226, 236, $249,283,312-15,355,377,442,580-81$ (1963).

93. The storage gap can be measured as about 50 million tons of cereals. See note 54 supra. The cost of these cereals may be estimated at about $\$ 200$ per ton, in 1973 United States dollars, the 1973 average wheat price. U.N. Foon ASSESSMENT, supra note 1, at 7. The additional cereal cost is thus about $\$ 200$ per ton times 50 million tons, or about $\$ 10$ billion. Storage facilities and seed stocks would probably cost under $\$ 1$ billion. U.N. FOoD Proposals, supra note 19, at 174-75. The cost of a 1975 world reserve would thus be about $\$ 11$ billion in 1973 United States dollars. However, the minimum stock size will grow with population, so that the 1975 minimum reserve level would compound at about 2.4 percent per year to a 1985 level about 30 percent larger than the 1975 level. U.N. Foon Assessment, supra note 1 , at 90 . Thus, a reserve adequate for 1985 demand would cost 30 percent more than $\$ 11$ billion, or about $\$ 15$ billion. If accumulated over the 1975-1985 period in equal increments, the cost of establishing minimum world food reserves would be about $\$ 1.5$ billion per year in 1973 United States dollars.

94. The annual flow is the sum of $\$ 2$ to $\$ 2.5$ billion per year for food, $\$ 3$ billion per year to provide conditions necessary for inducing lower birth rates, and $\$ 1.5$ billion per year for storage and information. See pp. 1057, 1061 supra. It should be stressed that this requirement is expressed in constant, 1973, dollars. With inflation, the actual flow would be more, although purchasing power would be the same. For example, assuming a steady 
It should be remembered that the countries which are most likely to be catastrophically affected by failures in nutrition lie wholly in the market economy portion of the world: ${ }^{95}$ the very area of the world in which agroindustry and the governments of the developed market countries are most free to facilitate investment. A principal means of boosting a country's domestic investment is to create a favorable market for the country's exports, thereby boosting the foreign exchange earnings available to the country for domestic investment. Other means include the direct investment of funds, raw materials, or trained personnel. Private corporations, nation states, or international organizations can finance these investments by credit arrangements or can undertake the transfers directly, as when a multinational corporation expands its plants in a country.

For several reasons international trade is an important vehicle in achieving the level of investment needed to induce lower birth rates and increase food production in developing countries. A significant reason arises simply from the need. The $\$ 6.5$ to $\$ 7$ billion additional annual investment flow exceeds by at least $\$ 4$ billion the level of likely increases in foreign aid, including aid from oil-producing nations, multilateral credit, bilateral credit, or investment expenditures by multinational corporations. ${ }^{96}$ This gap could be closed by an increase in the foreign exchange earnings of developing market countries, an increase which can be induced by a combination of tariff preferences, nontariff barrier arrangements, and trade concessions ${ }^{97}$ from the de-

ten percent annual inflation, the 1980 flow would have to be about $\$ 9.5$ to $\$ 10$ billion, the 1985 flow about $\$ 15$ to $\$ 16.5$ billion, and the ten-year flow would be about $\$ 103$ to $\$ 111$ billion. However, this total is in addition to present aid and investment flows. At 1962-1972 trends, total world economic development assistance, including $\$ 3$ billion related to food, would run at about $\$ 21$ billion per year in 1973 United States dollars, or about $\$ 210$ billion for the ten-year period to 1985 . Note 19 supra; ODC AGENDA, supra note 43, at 193 (Table D-2). With ten percent annual inflation, this would accumulate to about $\$ 335$ billion. It is assumed that the $\$ 21$ billion annual flow, as measured in 1973 dollars, will continue through 1985 . Therefore the total ten-year investment and aid flow involved is the sum of $\$ 210$ billion (the projected current level) and $\$ 65$ to $\$ 70$ billion (the gap developed in this Note), or $\$ 275$ to $\$ 280$ billion, in 1973 dollars. The actual flow, at ten percent annual inflation, would be the sum of $\$ 103$ to $\$ 111$ billion and $\$ 335$ billion, or about $\$ 438$ to $\$ 446$ billion. Finally, this estimates only the ten-year cost. After 1985 the investment and aid flow would have to continue at some, possibly reduced, level through the next several decades.

95. See p. 1053 supra.

96. See notes 19, 94 supra. The upper limit of new additional food-related aid has been estimated at about $\$ 2.5$ billion per year. U.N. Food Proposals, supra note 19 , at 9 . Subtracting this $\$ 2.5$ billion of possible new food aid from the $\$ 6.5$ to $\$ 7$ billion total additional annual need leaves a minimum annual gap of $\$ 4$ to $\$ 4.5$ billion.

97. The effect of these arrangements is a relaxation in a nation's trade barriers that permits designated goods to cross the nation's borders and sell at a cheaper cost to importers than would otherwise prevail. Thus, an import preference on a good from an exporting country can lower the price of the good in the importing country, thereby tending to increase the market and sales for the good or provide an incentive to im- 
veloped market countries. Under such trade arrangements, the developing market countries could sell more of their products in importing markets because the buyers would be offered lower and more attractive prices. ${ }^{98}$

Closing the $\$ 6.5$ to $\$ 7$ billion annual gap in foreign exchange earnings would require a 16 percent increase in the 1973 level of nonpetroleum exports of developing market countries to developed market countries.90 The required increase would fall to 10 percent if, due to increased aid, credit arrangements, or international corporate investment, the gap were diminished to $\$ 4$ billion per year. ${ }^{100}$ Few analyses have been completed which establish the total potential foreign exchange earnings which beneficial trade arrangements can provide to developing market countries, and there is a need for such statistics. ${ }^{101}$ The following calculations are based on available data and are presented to estimate the order of magnitude of the potential impact of trade arrangements on world nutrition.

As to tariff preferences, the potential for manufactured goods may be estimated to be about $\$ 0.7$ to $\$ 2$ billion in 1973 United States dollars. ${ }^{102}$ Adding the potential for semi-manufactured goods and primary products, the total potential could conceivably double, to $\$ 1.4$

porters in the importing country. The end result would tend to be increased foreign exchange earnings in the exporting country. Trade barriers are generally designated as either tariff (a direct tax impost) or nontariff (by far the larger barrier category, and including virtually any law or practice that impinges on trade, such as quotas, licensing systems, and industrial standards). The term "preference" appears with the term "concession" in the literature and legislation. "Concession" is generally confined to reciprocal lowering of trade barriers on a most favored nation basis, so that the terms of the arrangement apply equally to all trading partners of the countries granting the concession. "Preference" is generally applied when a country unilaterally lowers its tariff barrier; with respect only to selected trading partners, thereby giving those partners a competitive advantage over other countries that export goods to the country granting the preference. Such differential treatment of trading partners is also possible with respect to nontariff barriers: lowering of nontariff barriers can be selectively granted, thereby giving the selected countries a competitive advantage. For a summary of the types and roles of trade barriers, see generally SENATE TRADE ANALYsIS, supra note 29.

98. Id. at 59. In general, some portion of the additional foreign exchange earnings would have to be used to sustain the industry that generated the earnings. However, the task of the exporting country would be to use fiscal and other policies to divert as much as possible of the foreign exchange earnings to uses that increase food production and tend to lower birth rates. See note 65 supra.

99. Total nonpetroleum exports from developing market countries in 1973 were about $\$ 61$ billion, of which about 70 percent, or $\$ 42$ billion, were exports to developed market countries. See note 43 supra. The $\$ 6.5$ to $\$ 7$ billion gap in foreign exchange earnings represents about 16 percent of the $\$ 42$ billion figure.

100. See note 96 supra.

101. Telephone interview with Guy F. Erb, Senior Fellow at the Overseas Develop. ment Council, Washington, D.C., Feb. 12, 1975 (notes on file with the Yale Law Journal).

102. In the fall of 1971 the potential was estimated at $\$ 0.5$ to $\$ 1.5$ billion. Cooper, Third World Tariff Tangle, ForEIGN Policy, Fall 1971, at 35, 39; Fried, How Trade Can Aid, id. at 51,60 . Adjusting for inflation, this range becomes $\$ 0.7$ to $\$ 2$ billion in 1973 dollars. 
to $\$ 4$ billion..$^{103}$ The addition of a broad program of selectively administered nontariff barrier agreements ${ }^{104}$ could again double the exchange earnings induced on all types of products. ${ }^{105}$ Moreover, it is possible that certain trade concessions, as opposed to the more selectively applied preferences, ${ }^{106}$ can be negotiated which would enlarge the net foreign exchange earnings of developing market countries, even though the concessions applied to all trading nations, and not just to selected countries. ${ }^{107}$ Thus, the total potential new earnings can be estimated at roughly $\$ 2.8$ to $\$ 8$ billion. ${ }^{108}$ The potential United States contribution to that total can be estimated at about $\$ 0.8$ billion to $\$ 2.4$ billion. $^{109}$ To achieve this potential, several categories of manufactured goods as well as of semi-manufactured goods and primary products would have to be added to the list of imports eligible for United States tariff preferences. In addition, the United States would have to undertake a lowering of nontariff barriers, selectively negotiated and applied, which would benefit the developing market countries. ${ }^{110}$

In order to fulfill the total potential induced earnings, the other developed market countries would also have to expand their lists of eligible products and offer selectively administered agreements on

103. Developed market country imports of semi-manufactured and primary products from developing market countries are over four times as great as imports of manufactured goods. ODC AGENDA, supra note 43, at 161-62 (Tables B-4, B-5). However, some categories of these products already enjoy preferential treatment, so that the potential foreign exchange induction effect of trade preferences for semi-manufactured and primary products may be double, but not quadruple, that of preferences on manufactured goods. Interview with Erb, supra note 101 .

104. See note 97 supra (a description of these arrangements).

105. Interview with Erb, supra note 101. The effect of such nontariff barrier agreements could be greater; however, little analysis has been completed on the foreign exchange effects of nontariff agreements. $I d$.

106. See note 97 supra.

107. Interview with Erb, supra note 101 .

108. Some commentators have characterized the potential earnings from preferential trade arrangements as minor. See, e.g., Ghai, Africa, the Third World and the Strategy for International Detelopment, in Africa IN World Affairs: The NeXT ThIRTY Years 245 (A. Mazrui \& M. Patel eds. 1973); Abbai, Some Aspects of Trade and Development and Mohammed, Notes on the Common Market and Africa, in AFriCA AND THE WORLD 85, 126 (R. Gardiner, M. Anstee \& C. Patterson eds. 1970). However, these sources appear to have considered only the effects of lowered tariff barriers, without consideration of lowered nontariff barriers, and are based on the present volume of manufactured exports from developing market countries, without projecting likely growth in those manufactured exports. In addition, little or no quantitative data are offered to support the characterization. Id. at 79.94, 122.27; AFrICA IN WORLD AFFAIRs, supra, at 235-51.

109. About 20 percent of developing market country sales are to the United States and 50 percent to the remaining developed market countries. Thus, two-sevenths (20 percent divided by the sum of 20 percent and 50 percent) of developing market country exports to the developed market countries are to the United States. See note 43 supra. Therefore, the potential United States contribution to the \$2.8 to $\$ 8$ billion potential from all developed market countries may be estimated to be about two-sevenths or about \$0.8 to $\$ 2.4$ billion.

110. Interview with Erb, supra note 101. 
nontariff barriers. ${ }^{111}$ Probably, the European Economic Community would entertain these steps only if the United States were to do so. ${ }^{112}$

There are other reasons for the importance of international trade agreements in stabilizing world nutrition. Trade agreements, once in force, do not in general have to be renegotiated each year and so can be more stable than year-to-year allocations of foreign aid. Also, in many cases, trade brings in less expensive goods, tending to lower prices in the importing country and thereby enhancing the political acceptability of the trade agreements involved and helping to overcome potential union and industry resistance. ${ }^{113}$ Finally, international negotiations on trade provide an arena in which the fiscal planning and policymaking authorities of the participating governments can communicate directly with their counterparts in other governments in order to promote and plan the specific fiscal steps needed to translate increased foreign exchange earnings into new food production capacity, employment opportunities, increased literacy, health and family planning programs, and consumption of new food production by those who need the food..$^{114}$

\section{B. Legitimacy of Using Trade to Attack Nutritional}

Instability: The Right to Nutrition and the Right to Plan the Birth of Children

Principal objections to this role for trade and trade negotiations are that preferential trade agreements inhibit free trade by simply embellishing and readjusting the network of barriers that nations use in regulating foreign trade and that, at any rate, including population size and food production capacity as matters to consider in fashioning trade arrangements affronts the political sovereignty of the trading partners involved. However, virtually all of the world's trading na-

111. Id.

112. Id.

113. Increased competition from overseas producers can decrease the sales and employment in competing domestic industries, creating a need for interim compensation for the affected sector during the transition period of adjustment to the new foreign competition. Direct compensation for affected workers and firms is provided in the Trade Act of 1974. Trade Act, supra note 3, $\$$ 251-74, 19 U.S.C.A. $\$ \$ 2341-74$ (Supp. 1975). Given this provision, it appears to be in the interest of the United States generally to lower both its tariff and nontariff barriers, even after consideration of the issues of monetary exchange rates, trade balance, and the difficulties of securing reciprocal treatment from trading partners. Bergsten, Future Directions for U.S. Trade, 55 AM. J. AG. EcoN. 280 (1973) (also Reprint No. 275, Brookings Institution).

114. Richard N. Gardner, Professor of Law at Columbia University has forcefully called for such interdisciplinary discussions, in which the responsibilities of both developed and developing countries for food, population, and trade matters are explicitly discussed. Farnsworth, $A$ Global 'Survival Pact' Among Nations is Urged, N.Y. Times, Nov. 11, 1974, at 1, col. 6 . 
tions have endorsed the plans of action on world population and world food drafted in Bucharest and Rome, thereby acknowledging the common need of humankind to increase food production in developing market economy countries; ${ }^{115}$ to lower birth rates, taking full account of the relationship between birth rates and economic and social development; ${ }^{116}$ and to keep the world's population in balance with the earth's ability to nourish humankind. ${ }^{117}$

Moreover, the World Food Conference inserted an authoritative pronouncement into the flow of decisions that constitutes international law, affirming the right of each individual in the world to calories, minerals, and vitamins sufficient to develop fully his or her physical and mental faculties. ${ }^{118}$ This is a significant statement because it was endorsed by the official representatives of 133 governments ${ }^{119}$ and thus formally reiterates the rights to nutrition implied in the United Nations Charter ${ }^{120}$ and the Universal Declaration of Human Rights ${ }^{121}$ and the right to freedom from hunger declared in the International Covenant on Economic, Social and Cultural Rights. ${ }^{122}$ This right to nutrition shares the weakness of many other declared human rights in that no particular sanctioning measures are established to secure it. Yet the consistent flow of communication in recognition of the right exhibits an increasing intensity in the demands and expectations of the larger community in relation to the right, and such increasing intensity is likely to lead to more effective measures for securing the right.

The population conference added to the stream of formal declarations of international law by reaffirming the right of each family to decide the number and spacing of their children and to have the information and means to do so. ${ }^{123}$ Thus, governments have a duty

115. U.N. ROME REPORT, supra note I, at 72 .

116. Id. at 1; U.N. Bucharest REPORT, supra note 27, at 8, 10 (World Population Plan of Action $\{$ T $14(\mathrm{~b})-(\mathrm{g}), 17-19)$.

117. Id. at 37 (Resolution VIr of the World Population Conference).

118. U.N. ROME REPORT, supra note 1, at 3; see note 22 supra.

119. Id.

120. U.N. ChArter preamble, art. 1, art. 55. Article 55 provides in part: "With a view to the creation of conditions of stability and well-being...the United Nations shall promote.... solutions of international economic, social, health, and related problems ...."

121. G.A. Res. 217, U.N. Doc. A/810 at 71 (1948), which provides in Article 25 that: Everyone has the right to a standard of living adequate for the health and wellbeing of himself and of his family, including food, clothing, housing and medical care....

122. International Covenant on Economic, Social and Cultural Rights, G.A. Res. 2200, annex, art. II(2), 21 U.N. GAOR Supp. 16, at 49, U.N. Doc. A/6316 (1966).

123. U.N. BUCHAREsT REPORT, supra note 27, at 8, 21 (IIT 14(f), 27-29 of Wortd Population Plan of Action). This is a reaffirmation of the unanimous adoption in 1968 by the United Nations Conference on Human Rights of the Teheran Proclamation that family planning is a basic human right and a reaffirmation of a resolution that couples also 
to enable their citizens to limit family size and to educate citizens concerning the consequences of excessive population growth. This declaration was subscribed by 136 governments. ${ }^{124}$ Like the Rome declaration on the right to nutrition, this pronouncement creates no immediate judicial standing or sanction, but does at a minimum join similar pronouncements in creating the expectations called customary international law. ${ }^{125}$ Recognition of this right can entail not only direct expenditures on family planning services, but also pursuit of general nutritional stability, since the right is rendered meaningless for the couple whose children will be so malnourished that their life expectancy and prospect for healthy growth are severely diminished.120

In the light of these declarations, when a country includes stabilization of world nutrition as one of the goals to be pursued in its trade arrangements, it is working in pursuit of a shared international goal, as well as helping to avoid a 1985 world of severe dislocations, a world in which the people of many countries cannot nourish themselves and in which the people of many others rest their nutrition on a fragile balance of trade in one or two export products. ${ }^{127}$

III. The Stakes for Americans and the Provisions of the Trade Act of 1974

American interests in world nutrition warrant incorporation of nutritional stability as an important objective in trade negotiations, and the Trade Act of 1974 permits such incorporation.

\section{A. The Stakes}

Religious and Moral Integrity. At issue is the effectiveness of the commitment to the goals of human dignity espoused by individual Americans, and by religious and lay organizations. According to dec-

have the right to be sufficiently instructed and informed on family planning. STAFF of The U.N. FUnd for Potulation Activities, LAw and World Population, U.N. Doc. E/CONF. 60/BP/6, at 8 (1974). See Declaration on Social Progress and Development, G..1. Res. 2542 art. 22b, 24 U.N. GAOR Supp. 30, at 49, U.N. Doc. A/7630 (1970) (asserting that the right to family planning entails a right both to knowledge and to necessary means). 124. U.N. BUChAREST REPORT, supra note 27 , at 52.

125. See note 2 supra.

126. See note 1 supra.

127. After affirming the right of the individual to adequate nutrition (see note 2 supra), the nations attending the World Food Conference affirmed that:

the eradication of hunger is a common objective of all the countries of the international community, especially of the developed countries and others in a position to help.

U.N. ROME REPORT, supra note 1 , at 57. 
larations made by authoritative delegations from the overwhelming majority of nations, all humans have a right to an equitable share of the earth's resources, adequate nutrition, and effective family planning. ${ }^{128}$ These declarations give individuals, churches ${ }^{129}$ and synagogues, ${ }^{130}$ citizens' lobbies, and public interest organizations additional and compelling standing to work for fulfillment of these rights through dialogue with elected and executive government officials. ${ }^{131}$ The possibility of catastrophe in the form of famine and disease heightens responsibility, ${ }^{132}$ and, although no judicial claim or sanction can now be asserted by individuals based on these rights, governments and nongovernmental organizations may invoke these declarations in efforts to move a nation's policy toward making the rights effective.

Personal and National Security. The present condition of world nutrition confronts Americans with risks to security and safety. The risks vary in imminence and severity, but jointly they warrant action by Congress, the executive branch, and concerned religious, citizen, and business leaders.

The crush of undernutrition and a rising population in the Group I and Group II countries can lead to political instability. Under current trends, many Group I and II governments could fall, and students of the nutrition and population problem have acknowledged the high

128. See pp. $1066 \cdot 68$ supra.

129. John Coleman Bennett, former president of Union Theological Seminary in New York, has written a thoughtful and comprehensive book examining the Christian individual's call to engage in foreign affairs matters. J. BENNeTt, Foreign Policy in Christian Perspective (1966). He begins his book:

There are many reasons why foreign policy creates acute problems for Christian ethics, indeed for any sensitive and humane ethics. Yet, Christians and others who have similar ethical concerns must continually make decisions in this area. They struggle as citizens and as policy-makers to find the best, or the least destructive, policy open to them. There are no Christian foreign policies, but Christians should be moved and guided by their faith and commitment to seek the best policies in the circumstances.... I have already mentioned such objectives as an open world and the conditions of peace. When I discuss national interest, I shall have much to say about the American national interest in the welfare of other nations and in a reasonable stability in the international situation, though not in a status quo rigidly pro. tected against all radical change.

Id. at 11, 19-20. Charles W. Powers, Associate Professor of Social Ethics at the Yale Divinity School, has been examining the question of ethics specifically in the context of trade and reaches conclusions similar to Bennett's. C. Powers, Ethics and U.S. Trade Arrangements, 1974; Some Issues in Specifying Ethical Criteria for the Regulation of Multinational Corporations, 1974 (manuscripts prepared for forthcoming publication) (on file at the Yale Law Journal).

130. For Jews, the call to the individual to engage national leaders in dialogue concerning foreign affairs is at least as old as the call to the major and minor prophets. See, e.g., Isaiah 6; Hosea 1; Amos 1, 7.

131. A clearinghouse for action by religious groups on world nutrition issues is IMPACT, an interreligious organization supported by Protestant, Catholic, and Jewish funds which works to affect federal public policy. (IMPACT is located at 110 Maryland Avenue, N.E., Washington, D.C., 20002.)

132. See note 50 supra. 
likelihood of such collapses, some concluding that they are inevitable..$^{133}$ The ensuing new regimes might well shift away not only from a free market allocation of resources but also from present international political alignments. The model of a centrally planned economy and communal philosophy would be the obvious and attractive alternative; indeed, some observers conclude that only regimentation following the model of the People's Republic of China can hold down population, provide nutrition, and expand the economy within a developing country. ${ }^{134}$ Were such realignments to take place in such Group I countries as El Salvador, Honduras, India, Pakistan, Laos, or Ghana, ${ }^{135}$ the result would be a realignment of economic and political ties and erosion of United States influence in the affected continents. If a Group II country cannot sell enough exports, it faces the same possibilities of economic and political turbulence and realignment as the Group I countries. Thus, the political orientation of such countries as Bolivia and Panama ${ }^{136}$ may be at stake. Also, since the nations most severely threatened by nutrition shortages are the developing market countries, collapse of these economies would mark an ideological defeat for private enterprise. ${ }^{137}$ Finally, severe food shortages might stimulate acts of political or military coercion aimed at securing adequate food supplies. ${ }^{138}$

133. R. Heilbroner, Inquiry into the Human Prospect 35-40 (1974) [hereinafter cited as Heilbroner]; Interview with Robert $L$. Bard, Prof. at the Univ. of Connecticut School of Law, at New Haven, Feb. 25, 1974. Bard, author of Food Aid and INTERNATIONaL Agricultural Trade (1972), indicated that Mr. Heilbroner may well be right.

134. Heilbroner, supra note 133 , at $35-40$.

135. See note 34 supra (a listing of Group I countries).

136. See note 38 supra.

137. Collapse probably would not mean, however, a significant loss of markets or sales. See Drucker, Multinationals and Developing Countries: Myths and Realities, 53 FOREIGN AFFAIRS 121, I22-24 (1974).

138. The world may well move to a condition in which political or personal pressures could precipitate either nuclear blackmail or aggravated levels of conventional acts of coercion and terrorism whether anything is done about hunger or not. See, e.g., M. Willrich \& $T$ T. TAYlor, Nuclear Theft: Risks and Safeguards 107-19 (1974). However, if unabated, the pressures of hunger alone could precipitate such acts; cf. Turner, Hearst Captors Step Up Demands, N.Y. Times, Feb. 22, 1974, at 1, col. 5. But see G. BALL, ThE Discipline of Power 222 (1968):

The world has, in fact, lived one-third rich and two-thirds poor for thousands of years .... and, while mass communications may exacerbate resentments and encourage violence, the ultimate arbiter remains what it has been since the beginning of time, the possession of power. The power of the poor countries is definitely limited; they can create local situations of violence or instability and can appeal to the conscience or cupidity of the industrialized nations, but they do not, by themselves, have the ability to precipitate great power conflict or-at least until the Chinese make further nuclear progress-to involve the world in atomic war.

.....

Priorities have not been changed by improved communications or even a more active social conscience; our first need is to maintain an effective balance between East and West while at the same time encouraging those winds and currents that can bring about fundamental changes in attitudes and policies of the Communist countries so as to improve the prospects for long-term peace. 


\section{B. The Provisions of the Trade Act of 1974}

The Constitution assigns the power to regulate foreign trade largely to the Congress, ${ }^{139}$ although Congress can delegate foreign trade power to the executive branch. ${ }^{140}$ The Trade Act of 1974 delegates substantial authority to the President to engage in a five-year round of trade negotiations; it gives him a broad range of powers to restructure United States trading relationships, ${ }^{141}$ and it thereby permits or invites a variety of actions to stabilize world nutrition. The Act empowers the President to embark on a series of negotiations in which he can substantially adjust the present tariff and nontariff barriers which govern the flow of goods into and out of the United States. In fact, it is unique in the history of congressional delegations of trade negotiating authority because it authorizes the President to negotiate reductions of nontariff barriers, which, for many commodities, pose greater obstacles to trade than tariff barriers. ${ }^{142}$ United States negotiations will be administered by personnel from the Office of the Special Representative for Trade Negotiations, in the Executive Office of the President. ${ }^{143}$ The executive branch must hold open public hearings on trade negotiations, ${ }^{144}$ and each nontariff trade barrier agreement is subject to congressional veto. ${ }^{145}$

With respect to developing countries, the Act provides that one of the United States negotiating objectives shall be "to enter into trade agreements which promote the economic growth of both developing countries and the United States and the mutual expansion of market opportunities." ${ }^{146}$ In the course of the hearings, Administration wit-

139. U.S. Const. art. I, $\$$ 8. See generally L. Henkin, Foreign Affairs and the Constiturion 31-35, 44-45, 56-71, $129-88$ (1972).

140. For a brief history of recent delegations, see Senate Trade Analysis, supra note 29 , at 1-2.

141. Trade Act, supra note 3, $\$ \$ 101-02,19$ U.S.C.A. $\$ \$ 2111-12$ (Supp. 1975).

142. SEnATE Trade ANALYSIS, supra note 29, at 1, 81-97.

143. Trade Act, supra note 3, \$ 141, 19 U.S.C.A. \$ 2171 (Supp. 1975).

144. Id. $\$ 133,19$ U.S.C.A. \$ 2153 (Supp. 1975).

145. Id. $\$ \$ 151-54,19$ U.S.C.A. $\$ \$ 2191-94$ (Supp. 1975).

146. Id. $\$ 106,19$ U.S.C.A. $\$ 2116$ (Supp. 1975). Section 103 describes the overall negotiating objective: "[to] obtain more open and equitable market access and the harmonization, reduction, or elimination of devices which distort trade or commerce." Section 104 sets as a principal negotiating objective export opportunities for United States products substantially equivalent to import opportunities granted by the United States. Section 105 permits bilateral, as opposed to multilateral, agreements when appropriate. Section 107 sets as a principal objective the implementation of a set of temporary safeguards to ease the disruption in the domestic economy caused by new trade arrangements, and $\S 108$ sets as a principal objective fair access by the United States to foreign raw materials. During the coursc of the Act's passage, the characterization of $\$ 106$ as a principal objective was deleted. Compare id. with H.R. 10710, 93d Cong., 2d Sess., \$§ 10308 (Dec. 13, 1974). Nevertheless, executive branch witnesses have stressed the importance of preferential treatment of developing countries, see note 147 infra, and there is the quid pro quo aspect of the relationship between $\S 106$ and $\S 108$ : it is developing market countries that control many raw materials, so that "fair access" by the United States to raw materials may require special attention to developing country needs. 
nesses stressed the importance of the role of economic development in enhancing international political stability. ${ }^{147}$ Under the Act the President has the power to enlarge the list of United States imports of manufactured, semi-manufactured, and primary products eligible for tariff preferences in the form of duty-free treatment ${ }^{148}$ and selectively to negotiate the provision of both nontariff ${ }^{\mathbf{1 4 0}}$ and tariff benefits with developing countries, without simultaneously granting identical benefits to all other United States trading partners. ${ }^{150}$ Thus, developing market countries can be assisted by agreements which, if universally and contemporaneously applied to all trading partners, could disrupt the domestic United States economy to an extent that would make the program infeasible.

\section{Action}

The Executive Branch. Given the provisions of the Trade Act, and the stakes for Americans posed by a 1985 world in which current nu-

147. See, e.g., Trade Hearings, supra note 42, at 219-20 (testimony of William $D$. Eberle, Special Representative for Trade Negotiations); id. at 487, where Secretary of State Kissinger stated that

the less developed countries want, and importantly need some access to the markets of the industrialized countries while they are building up their own industry. And this is one of the reasons why we have supported a system of general preferences with the safeguards that are built in. An attempt has to be made to close the gap between the developing and developed nations, or at any rate, to bring about economic progress in the developing nations so that their instability is not a constant source of tension in international affairs.

(Emphasis added.) For a survey of the general support and notice of reservations accorded this position, see Staff of the Senate Comm. on Finance, 93d Cong., 2d Sess., Digest of TESTIMONY ReCeIved on H.R. 10710-The TRADE Reform ACT of 1973, at 74-79 (Comm. Print 1974).

148. Trade Act, supra note 3, $\$ 503$, 19 U.S.C.A. $\$ 2463$ (Supp. 1975).

149. Id. $\$ 102$, 19 U.S.C.A. $\$ 2112$ (Supp. 1975). In explaining the intent of the Act, the Senate Report states:

As passed by the House, the bill represented the largest delegation of trade negotiating authority to the Executive in history. The Finance Committee's amendments seek to establish appropriate and constitutionally-sound guidelines and criteria to govern the exercise of the authority granted by the bill. The intractable nature of modern barriers to trade, both tariff and nontariff, make this grant of extensive negotiating authority to the Executive necessary.

Senate Trade Act Rerort, supra note 43, at 14-15 (emphasis added).

150. With respect to tariff preferences, it is the intent of Title $V$ of the Trade Act to permit such preferential treatment of developing countries. Trade Act, supra note 3, $\$ \$ 501-05,19$ U.S.C.A. $\$ \$ 2461-65$ (Supp. 1975). SENATE TRAde ACT REPORT, supra note 43, at 41,219 . With respect to nontariff arrangements, the Act provides that:

The President may also recommend with respect to any such [nontariff barrier] agreement that the benefits and obligations of such agreement not apply uniformly to all parties to such agreement, if such application is consistent with the terms of such agreement.

Trade Act, supra note 3, $\$ 102(f), 19$ U.S.C.A. $\$ 2112(f)$ (Supp. 1975). This provision was added by a Senate amendment specifically to "afford developing countries an opportunity to participate in NTB [nontariff barrier] agreements." STAFF OF THE HOUSE CoMM. ON IVays and Means \& the Senate Comm. on Finance, 93d Cong., 2d Sess., Summary of Senate Amendments to H.R. 10710, at 3 (Conf. Comm. Print 1974). See Senate Trade. ACr REPORT, supra note 43 , at 77-78. 
trition trends are unabated, the President can and should use his authority under the Act to reach three objectives:

(1) the policy should be to integrate the developing market countries into trade negotiations in order to encourage and enable the Group I developing market economy countries to increase their domestic food production to a level that will bring their 1985 nutrition gap within bounds that can be met by their foreign exchange earnings or by aid, and, similarly, to encourage and enable the Group II and Group III countries to expand their food production, in order to extend the nutritional self-sufficiency of Group II countries and to. reinforce the supplies available from the developed countries; ${ }^{151}$

(2) the United States should encourage and enable the developing market economy countries to stabilize their population by reducing their birth rate per 1000 to 25 by 1985 and to balance with their death rates by the year 2000; ${ }^{152}$

(3) the policy should be to encourage other developed market countries to provide favorable tariff and nontariff trade arrangements to assist the developing market countries to reach these goals.

Thus the analytical task of the executive branch is to identify and examine each developing market country's present food and population programs and determine the amount and kind of any further investment needed to make that country's projected food production and population growth rates compatible with the stabilization of world nutrition. This type of country-by-country analysis is expensive in terms of personnel resources but is essential, in view of the American interests that are at stake, and the executive branch has the personnel

151. The need to integrate developing countries into trade negotiations has been succinctly expressed by Dharam Ghai:

[T] here is no evidence that the interests of the least developed countries are receiving the necessary attention in discussions either over the issue of coverage of preferences or in the negotiations among the developing countries on trade concessions which have been conducted for some time under the auspices of the General Agreement on Trade and Tariffs. One could give other examples from recent discussions of international economic problems, but the general point has been made that when it comes to concrete policies, the special interests of the least developed countries will continue to be neglected unless well meaning resolutions are backed by appropriate machinery.

AFrica in WorLd AFFaIRs, supra note 108, at 250-51.

Admittedly, this will enlarge the scope of considerations and tasks to be undertaken by trade negotiators. However, in the larger context of the problem of world nutrition, trade arrangements are an integral part of both the problem and its solution. The necessarily enlarged scope of trade negotiations urged in this Note suggests that henceforward trade negotiations should be carried on continuously, in a permanent forum, rather than undertaken as intermittent events.

152. See p. 1059 supra. It must be stressed that population size in the United States and the other developed countries must be stabilized as well. See id. 
resources to accomplish the task. ${ }^{153}$ In addition, increases in the foreign exchange of many developing market countries may not be realized until several years after 1975 , because the trade negotiations will take place over several years. ${ }^{15 \pm}$ For the interim, the executive should request augmentation of direct aid allocations by an amount at least sufficient to initiate the necessary nutrition stabilization programs in the Group I countries.

The executive's negotiating task would be to secure compliance with the stabilization goal, using trade arrangements both as a foreign exchange conduit and as a bargaining counter to ensure that the resulting international trade structure conveys the resources necessary to stabilization and that the resources are used for that purpose. ${ }^{155}$ Most of these trade arrangements should result in lower prices for American consumers, but some may functionally constitute aid, if they instead result in a net cost to the United States in terms of jobs and prices. However, if this form of aid is in small increments over the years and is politically feasible, ${ }^{150}$ it is preferable to the risks of a 1985 world in which nutrition gaps cannot be filled.

Agroindustry. At a 1974 meeting in Toronto, 145 agroindustry institutions and firms met and identified the steps they were prepared to take in order to support the work of the World Food Conference. ${ }^{157}$

153. The Trade Act authorizes the Office of the Special Representative for Trade Negotiations to employ officers and other personnel, use consultants, and, with their consent, draw on the services, personnel, and facilities of other federal agencies. It also authorizes the appropriation of funds necessary for carrying out the Office's functions. Id. $\$ 141$ (d), 19 U.S.C.A. $\$ 2171$ (d) (Supp. 1975).

154. Trade Act, supra note 3, \$101(a)(1), 19 U.S.C.A. \$2111(a)(1) (Supp. 1975).

155. With most developing market countries, these negotiations would in large part center on enhancing the probability of success of programs already under way or under consideration. See generally Population and Development Statements, supra note 71. For example:

In the latter months of 1973, the Mexican Government adopted a new General Population Act radically changing the official position underlying the legislation in force since 1947, which had been pro-natalist. The Government has indicated that the new population policy will not be a substitute for economic development, but will be incorporated into and form an important part of that strategy.

The Act states that its purpose is "to regulate the phenomena which affect the size, structure, dynamics and distribution of the population in the national territory, in order to enable it to share in a fair and equitable manner the benefits of economic and social development' and seeks in particular 'to stabilize the growth of the popula. tion, and to achieve a better use of the country's human and natural resources.' Id. at 44 (emphasis added). In subsequent years, if a developing market country that has been granted preferential trade arrangements as assistance for stabilizing world nutrition disavows its commitment to the necessary food production and population growth goals, the President can choose to provide no further preferential arrangements to the country or, in extreme cases, terminate the arrangements according to terms embodied in the trade agreement granting the original benefit.

156. A factor enhancing the political feasibility of such preferential arrangements is the Trade Act provision for direct government compensation of workers and firms that are adversely affected by agreements under the Act. See note 113 supra.

157. U.N. AGRoINDUSTRY REPORT, supra note 16, at 1 . 
Though general in its terms, the final conference declaration announced that the institutions and firms "agreed that the key to solving. the world's food problem is increasing agricultural production in the developing countries." 158 They pledged to increase their participation in agriculture in the developing countries. ${ }^{15 \mathrm{~g}}$ The analytical task of agroindustry firms and institutions is to acknowledge the implications of the risk to their own survival of the presently likely 1985 world, posed by possible abandonments of the market system, political instability, terrorism, and war. Their entrepreneurial and managerial task is to act now, in cooperation with world governments, to stabilize the world nutrition system by increasing food production in developing market countries and facilitating the economic and social development in those countries needed to induce lower birth rates.

Citizens' Groups. Citizens' organizations, including religious groups, ${ }^{160}$ citizen lobbies, ${ }^{161}$ and public interest legal organizations, ${ }^{162}$ should act in five ways. First, since the Act itself calls for hearings to be held before the trade talks, these organizations should attend the hearings and press for the executive branch to pursue the analytical and negotiating tasks necessary to use the trade negotiations to move the world nutrition system toward stabilization. Citizens' groups would play an essential role in the hearings by counterbalancing the vigorous but often narrow advocacy of special industry interests. Second, groups with stock portfolios should use their shareholder's rights to commit agroindustry corporations to working for a stabilized world nutrition system and to testifying favorably for such stabilization at the trade negotiation public hearings. This commitment can be sought through shareholder proxies and through direct contact with management. ${ }^{163}$

158. Id. at 2 .

159. Id. There is evidence that cooperation between agroindustry corporations and developing market countries can be effective in increasing food production and employment of labor in the host country and profitable for participating corporations. See, e.g., Vicker, Multinational Firms Help Poorer Nations to Boost Food Output, Wall St. J., Mar. 18, 1975, at 1 , col. 6. A valuable center and clearinghouse for domestic and international research on business and agriculture is located at the Harvard Business School, under the supervision of Professor Ray A. Goldberg.

160. Representative church and synagogue groups include the Washington Interreligious Task Force on World Hunger in Washington, D.C., the National Council of Churches, the leadership of the branches of the Jewish faith and of the several Christian denominations, the Corporate Information Center of the Interfaith Center on Corporate Responsibility, in New York City, and IMPACT, supra note 131.

161. Representative organizations include Consumers Union, Common Cause, and the Council on National Priorities and Resources.

162. Representative organizations include the Center for Responsive Law in Washington, D.C., the Council on Economic Priorities in New York City, and the Agribusiness Accountability Project in Washington, D.C.

163. The Corporate Information Center and the Council on Economic Priorities, supra notes 160 and 162 , provide leadership and coordination on proxy issues and contacts with the management of corporations. 
Third, these groups should petition senators, representatives, and their staffs specifically to endorse and support steps by the executive branch to stabilize world nutrition. This task would include petitions urging creation of a world grain reserve, a measure which would require substantial negotiations among trading partners. Fourth, the groups should use their full political resources to reduce population growth and food waste in the United States. ${ }^{164}$ Finally, citizens' groups should mobilize grassroots political support for nutrition stabilization, in order to enhance their own impact on the executive and Congress.

Congress. Congress should specifically request and support executive branch efforts to incorporate stabilization of world nutrition as an objective of the trade negotiations. In doing so, Congress should by resolution approve such efforts and formally recognize and endorse the Bucharest and Rome plans of action on food and population. ${ }^{105}$ Since the Act requires congressional review of nontariff agreement settlements, ${ }^{166}$ Congress should approve those agreements necessary to stabilizing world nutrition and should fulfill requests by the executive branch for augmentation of direct food and food production aid to developing market countries during the interim in which preferential trade arrangements are being negotiated. In addition, members of Congress should stress this goal in informal contacts with White House, State, and Treasury Department personnel. Beyond the Trade Act, Congress should authorize and appropriate the funds for United States participation in a grain reserve system and in the international monetary institutions necessary to make nutrition stabilization possible, such as the World Bank. ${ }^{167}$

\section{Conclusion}

The present and projected world nutrition gap lies wholly in the developing market countries and is due primarily to insufficient food production and excessive population growth in those countries. The gap can be closed by initiating two new international investment programs in 1975 . The first program would entail about $\$ 2$ to $\$ 2.5$ billion per year for investment in food production in the developing market

164. See notes 33,75 supra. Because of the difficulty of changing these habits, the burden for effecting this step must rest on citizens' groups and on citizens themselves.

165. A model for such a resolution would be S. Res. 329, 93d Cong., 2d Sess., 120 Conc. REC. S14425 (daily ed. Aug. 7, 1974) (passed by Senate on Aug. 7, 1974). The resolution urged broad United States participation in increasing food production in less developed countries.

166. See note 145 supra.

167. See p. 1061 supra. 
countries through 1985 . The second program would entail additional investments in the same countries of about $\$ 4.5$ billion per year through 1985 to create the social and economic conditions necessary to stabilize their population at a level which can be nourished. The combined annual investment flow for both programs of $\$ 6.5$ to $\$ 7$ billion can be generated in substantial part by new trade arrangements granted by developed market countries. Under the Trade Act of 1974 the President of the United States has the power to negotiate trade arrangements sufficient to meet nearly one-third of the total $\$ 6.5$ to $\$ 7$ billion need. The President should use this power to provide those arrangements in exchange for effective commitments to use the additional trade earnings to reach the necessary food production and population stabilization goals. The President should also encourage the other developed market countries to provide trade arrangements sufficient to provide the additional annual flow of investment funds needed to reach the $\$ 6.5$ to $\$ 7$ billion total. Individuals, citizens' groups, religious organizations, and Congress should each vigorously urge the President to take these steps and support him in doing so. 